\title{
Can Mature Democracies Be Perfected?
}

\author{
Guy-Uriel E. Charles
}

Matthew J. Streb, Rethinking American Electoral Democracy. New York, NY: Routledge, 2008, 226 pp., \$31.95 (paperback).

$\mathbf{O}_{\mathrm{r}}$ NE OF THE MORE vexing questions about democracy that is often debated among political theorists, political scientists, and legal scholars is whether the democratic character of mature democracies can be improved. From one view, that of democratic realists, mature democracies are perfected as a matter of definition and as a matter of realistic expectations. Because mature democracies are those that respect core democratic principles, variations outside the core are simply policy differences based upon each democratic polity's willingness to engage in a different set of trade-offs. For democratic realists, variations in democratic practice that are not related to core democratic principles do not in any way call into question the democratic character of the polity. From another view, that of democratic perfectionists, even among mature democratic states that share core democratic commitments, there exist electoral deficiencies that call into question the democratic character of mature democracies. From the perspective of democratic perfectionists, democracy is a continuum and not a binary condition of either democratic or not. Given that democracy is a more-or-less proposition (as opposed to either-or), it makes sense to talk about perfecting mature democracies as there is a normative ideal vision to perfect toward.

In Rethinking American Electoral Democracy, Matthew J. Streb, a political scientist at Northern Illinois University, joins the debate more or less on the side of the democracy perfectionists. The book is a great and easy read. It moves through a lot of material without being burdensome. Some of the ar-

Guy-Uriel E. Charles is a Professor of Law at Duke Law School. guments are quite provocative. The book would be a great companion to any class on law and politics. It is an important contribution to the field.

Rethinking American Electoral Democracy is organized in three parts. In Part I, Professor Streb focuses on factors that affect turnout and argues that there are too many elections in the United States. Part II addresses ballot access and vote counting. There, Professor Streb argues for expansive ballot access laws and comes out in favor of optical scan voting machines. Part III explores broader national questions including congressional redistricting, the Electoral College, presidential primaries, and campaign finance reform. Professor Streb would like to have more non-partisan redistricting commissions, he is in favor of a national presidential primary, he would eliminate the Electoral College, and he would eliminate caps on campaign contributions.

Professor Streb states as his aim the articulation of "the conditions of a model electoral democracy" (2). This model is presented not as an unattainable ideal against which to assess the democratic character of a polity that calls itself democratic, but as setting forth realistic goals for a mature democracy such as the United States. Some of the conditions of Professor Streb's model electoral democracy include what almost all parties to this debate would agree are core commitments that ought to exist in every democracy and that separate democratic from non-democratic states. But they also include other types of commitments, such as non-burdensome electoral rules, about which there will be no consensus.

Though Professor Streb recognizes the contested nature of some of the principles that he espouses, he nevertheless views them as normative requirements. This point highlights a peril for democratic perfectionists, as they have to convince us that their proposed trade-offs are more compelling than the sta- 
tus quo and they have to defend the normative underpinnings of their argument. Consider for example Professor Streb's argument that campaign contribution limits should be eliminated entirely. This conclusion is based upon the contention that the problem of campaign financing is not that there is too much money in American elections but that there is too little (165). Professor Streb contends that if caps were removed, more money would be available to challengers, which would result in more competitive elections. This is because, he maintains, as an empirical matter the competitiveness of an election is determined not by the amount of money the incumbent spends but by the amount of money the challenger spends. Thus, even though incumbents would be able to also raise more money, because the marginal utility of the contribution would be greater to the challenger, permitting unlimited contributions would naturally level the playing field.

But eliminating contribution caps would exacerbate a serious equality problem in American politics. Professor Streb unhelpfully responds that current campaign finance regulations do not guarantee equality because "[f]ew people have the resources to donate the $\$ 2,300$ to one candidate, much less multiple candidates" (168). It is true that few people can donate up to the current caps, so some level of political inequality exists. Thus, if the goal of campaign contribution caps is to eliminate political inequality, they have not done so. But if one of the goals of contribution caps is to limit political inequality, Professor Streb's point is inapposite.

Moreover, his proposal would seriously exacerbate this problem and raise political inequality as a fundamental concern in American politics to an extent that it is not currently. Does one believe that politicians would not be disproportionately responsive to individuals and more problematically corporations who could potentially contribute hundreds of thousands of dollars each or who could potentially bundle millions? To the extent that political equality is currently not viewed as a problem in American politics, this proposal would assure that it is. To the extent that political equality is viewed as a problem, this proposal would exacerbate it by orders of magnitude. Economic inequality and political inequality would be mutually reinforcing forces in American politics with very little to moderate their potentially disastrous effects.
Professor Streb defends his recommendation on the ground that it would make elections more competitive. This assertion is in tension with his earlier definition of the competitiveness principle. As he defines the concept, the goal is not that each election is competitive in order for the electoral system to be legitimate; rather, the goal is that there must be the potential for competitive elections (3-4). Competition itself as a democratic value is ambiguous as a matter of definition. In its most controversial articulation, it instructs that the state arranges democratic institutions to create, artificially if need be, as much competition as possible by, for example, making all districts as competitive as possible or by changing campaign finance rules to make campaigns as competitive as possible. In its more restrained articulation, it simply implies that the state should not interfere with competitive electoral structures where they might otherwise exist. ${ }^{1}$ Consistently with this narrower and less contested definition of the principle, theorists, including Professor Streb, have defined competitiveness not as a goal but as a state. Thus, I have argued in previous scholarship that elections ought to be contestable, but not subject to a normative requirement that the state guarantee competitive elections. ${ }^{2}$ Professor Streb uses the phrase "potential" for competitive elections and Professor Kang, who has the most comprehensive and sophisticated exposition of this concept, uses "democratic contestation."3

Under current campaign finance rules elections are certainly contestable. That is, they are capable of being competitive. To use Professor Streb's phrase, there is the potential for competition. The state does not enforce one-party dominance or impose discriminatory burdens on challengers. Under Professor Streb's proposed change, elections must be as competitive as possible and the state must assure that they are so in the manner in which it promulgates campaign finance rules. This requirement of "as competitive as possible" is different from "competitive potential." Consequently, it compels a

\footnotetext{
${ }^{1}$ See, e.g., Daniel H. Lowenstein, Competition and Competitiveness in American Elections, 6 Election L. J. 278, 280 (2007).

${ }^{2}$ See Guy-Uriel E. Charles, Race, Redistricting, and Representation, 68 Оhіо State L. J. 1185, 1199 \& n. 53 (2007).

${ }^{3}$ See generally Michael Kang, Race and Democratic Contestation, 117 YALE L. J. 734 (2008).
} 
different justification, which Rethinking American Electoral Democracy does not offer.

Some, if not most, of the other arguments advanced by Professor Streb are generally unobjectionable and one does not need to be a democratic perfectionist to accept them. Take for example his argument that the combination of frequent elections, the consequence in part of decentralization in the electoral process, and onerous voting rules make voting too costly for the average citizen. Professor Streb points out that too many states schedule multiple elections in a given year-Georgia had five elections in one year - and many of these states have burdensome voting administration rules. This contributes to extremely low turnout for low salience and low information elections. His suggestions that polities consolidate elections and reduce the number of elective offices seem quite sensible. Similarly, his argument that if states are going to use direct democracy measures they should take rea- sonable steps regulating their use, such as limiting the number of initiatives that can appear on the ballot, seems also quite sensible.

It is not clear to me that Rethinking American Electoral Democracy will convince many people that there is such an attainable state as a model democracy. But Professor Streb has clearly succeeded in writing a thoughtful book with a plethora of sometimes counterintuitive but always well-argued proposals for incrementally improving American democracy.

Address correspondence to: Guy-Uriel E. Charles Duke Law School Science Drive and Towerview Road Durham, NC 27708

E-mail: Charles@law.duke.edu 